\title{
Melanin bleaching with potassium permanganate for melanocytic lesions diagnosis in veterinary medicine
}

[Despigmentação de melanócitos com permanganato de potássio para diagnóstico de lesões melanocíticas na medicina veterinária]

\author{
T.A. Moreira ${ }^{1}$, W.T. Blanca ${ }^{2}$, L.F. Gundim ${ }^{3}$, I.P. Castro ${ }^{1}$, A.A. Medeiros-Ronchi \\ ${ }^{1}$ Universidade Federal de Uberlândia - Uberlândia, MG \\ ${ }^{2}$ Centro Universitário Integrado - Campo Mourão, PR \\ ${ }^{3}$ Aluna de pós-graduação - Faculdade de Medicina Veterinária - \\ Universidade Federal de Uberlândia - Uberlândia, MG
}

\begin{abstract}
The aim of this study was to microscopically re-evaluate the melanocytic lesions diagnoses established by the Animal Pathology Laboratory of the Federal University of Uberlândia, in the state of Minas Gerais, Brazil, over a period of eleven years; in addition, to perform a comparative analysis between the conventional histopathological $(\mathrm{CH})$ method and the use of the melanin bleaching $(\mathrm{MB})$ technique with potassium permanganate, sulfuric acid, and oxalic acid solutions. The results of the MB method presented a disagreement in $24.32 \%$ of the diagnosis previously by $\mathrm{CH}$, with low agreement (61.0\%) and low Kappa coefficient (0.2267). Melanoma was the most frequent lesion, more frequent in elderly and nonbreed female dogs. The most frequent melanoma location was in the cutaneous tissue. The presence or absence of a pagetoid spread in cutaneous samples, distribution of melanin, pattern of cell layout, cell morphology, degree of cellular atypia, and the number of mitoses verified after MB were the most important criteria to confirm the diagnosis of malignancy or benignity of the lesions. Evaluating pathologists considered MB to be essential for the majority of diagnoses and an efficient complementary method for the diagnosis of melanocytic lesions, even in cases with a moderate degree of pigmentation.
\end{abstract}

Keywords: depigmentation, histopathology, melanotic pigments

\section{RESUMO}

Este estudo objetivou reavaliar microscopicamente os diagnósticos de lesões melanocíticas estabelecidos pelo setor de Patologia Animal da Universidade Federal de Uberlândia, em um período de 11 anos, e, com base nesse levantamento, realizar uma análise comparativa entre o método histopatológico convencional $(H C)$ e o método de despigmentação de melanócitos (DM) com permanganato de potássio, ácido sulfúrico e ácido oxálico. A DM revelou discordância em 24,32\% dos diagnósticos previamente estabelecidos por HC, apresentando baixa concordância (61,0\%) e baixo valor de coeficiente Kappa (0,2267). A alteração mais frequente foi o melanoma, com maior ocorrência em cadelas idosas sem raça definida (SRD). A localização mais frequente dos melanomas foi cutânea. A presença ou ausência de disseminação pagetoide nos casos cutâneos, a forma de distribuição da melanina, o padrão de disposição das células, a morfologia celular, o grau de atipia celular e a quantidade de mitoses verificada após a despigmentação foram critérios de elevada importância para firmar o diagnóstico quanto à malignidade ou benignidade da lesão. A despigmentação foi considerada pelos patologistas avaliadores como essencial para o diagnóstico na maioria dos casos, o que leva a concluir que ela constitui um método complementar eficiente no diagnóstico das lesões melanocíticas, mesmo em casos com grau moderado de pigmentação.

Palavras-chave: despigmentação, histopatologia, pigmentos melânicos

Recebido em 22 de agosto de 2017

Aceito em 18 de dezembro de 2018

E-mail: thais-vet@outlook.com 


\section{INTRODUCTION}

Melanocytic lesions are frequent in veterinary medicine, especially in dogs. These lesions may be neoplastic or non-neoplastic, and are defined as melanosis, melanocytoma, and melanoma (Bergman et al., 2013; Miller e Zachary, 2017).

Melanosis is a non-neoplastic lesion resulting from increased pigmentation in an area of tissue. This is common in an area of chronic inflammation. When this lesion is connected to other symptoms, it can be characterized according to its location (Robinson and Ruxtable, 2003; Gross et al., 2005; Rhodes and Werner, 2011). However, neoplastic lesions (melanocytoma and melanoma) are the most clinically relevant (Rhodes and Werner, 2011; Miller e Zachary, 2017).

Melanocytoma is a melanocyte benign neoplasm, most frequently found in the epidermis, dermis, hair follicle, and eyeball (Goldschmidt and Goldschmidt, 2017). However, melanomas are highly aggressive, malignant neoplasms that metastasize in a short period of time, whether they are pigmented (melanotic melanoma) or unpigmented (amelanotic melanoma) (Bergman et al., 2013).

The histopathology is the gold standard method for the diagnosis of these lesions, and since melanocytes can have various shapes and sizes (small or large, round, oval, fusiform, or multinucleate cells), an adequate microscopic evaluation is essential for the correct diagnosis (Goldschmidt and Goldschmidt, 2017).

However, melanotic pigments may obscure the cellular morphological characteristics; therefore, histological depigmentation techniques have been widely used in human medicine to evaluate the systematic criteria for diagnosis of these lesions (Veronese et al., 2007; Liu et al., 2013; Chung et al., 2016). On the other hand, in veterinary medicine, melanin bleaching methods have rarely been employed. Consequently, studies that evaluate the efficiency of histological depigmentation as an auxiliary tool used in the diagnosis of melanocytic lesions in domestic animals are necessary.

Thus, the objective of this work was to use a melanin bleaching technique in samples of melanocytic lesions from several animal species from the Animal Pathology Laboratory in the
Federal University of Uberlândia, diagnosed over a period of eleven years; then, to apply histopathological parameters used in human medicine to diagnose these lesions and, finally, to compare these results to previously obtained diagnoses using the conventional histopathology.

\section{MATERIALS AND METHODS}

Histopathological result protocols of the Animal Pathology Laboratory of the Federal University of Uberlândia (UFU), in the state of Minas Gerais, Brazil, were analyzed and the cases of melanocytic lesions diagnosed from January 2006 to December 2016 were selected for reevaluation. Epidemiological data such as species, breed, sex, age, and the location of the lesion were recorded. The cases of amelanotic melanoma (non-pigmented melanocytic neoplasia) were also recorded to observe their frequency, compared to pigmented lesions.

The pigmented sample cuts were embedded in paraffin $(4 \mu \mathrm{m}$ thick), arranged on histological slides prepared with poly-L-lysine. The melanin bleaching technique used was: potassium permanganate $(\mathrm{KMnO} 4)$ and sulfuric acid (H2S04) solution treated with oxalic acid (C2H2O4), as primarily described by Chesterman and Leach (1958). The slides were dewaxed in xylol, hydrated in ethyl alcohol aqueous solution, and washed with water. The slides were then immersed in a solution of $0.3 \%$ $\mathrm{KMnO} 4$ and $0.3 \% \mathrm{H} 2 \mathrm{~S} 04$ for fifteen minutes and washed with water. After that, they were immersed in a solution of $1 \% \mathrm{C} 2 \mathrm{H} 2 \mathrm{O} 4$ for a maximum of two minutes until the tissue was completely white and visible before being washed again. The slides were then stained with Hematoxylin and Eosin (HE) and mounted under cover slip.

The re-evaluation of the diagnoses was performed by two pathologists with expertise in blind studies; they read the slides from both lesions: those subjected to the $\mathrm{CH}$ and those subjected to the MB method. The microscopic evaluation included neoplastic and nonneoplastic lesions (melanosis). The more important criteria for microscopic melanocytic neoplasia diagnosis described in the literature (Veronese et al., 2007; Momose et al., 2011; Massi and Leboit, 2013; Goldschmidt and 
Goldschmidt, 2017) were selected and used in the samples.

The histopathological criteria considered in the $\mathrm{CH}$ slides were: amount of melanin in the sample (low, moderate, high), form of melanin distribution (uniform or non-uniform), and in cutaneous cases, the occurrence of an extensive pagetoid spread-the melanocyte migration to the epidermis upper layers. The samples subjected to the MB were analyzed considering the following criteria: lesions present in the affected tissue or organ (tissue necrosis, degeneration and epithelium loss or rupture), presence of cellular necrosis, cellular morphology (rounded, fusiform), distribution of neoplastic cells, degree of cellular pleomorphism, cytoplasmic appearance (broad or scarce), nuclear characteristics (size, shape, atypia), evidence of nucleolus, number of mitoses per field, presence of giant cells, and inflammatory reactions.

Considering the aforementioned criteria, the diagnoses were established, and the contribution of the melanocyte depigmentation technique on the lesion's histological diagnosis was evaluated by scores of 1 to 3 , wherein $1=$ ineffective, $2=$ significant, and $3=$ essential for the diagnosis The Kappa index of agreement was used for the comparative analysis between the two diagnosis methods - conventional and after melanocyte depigmentation - by using the program BioEstat5.0 (Ayres et al., 2007) with a 95\% confidence interval.

\section{RESULTS}

From January 2006 to December 2016 in the Animal Pathology Laboratory of the Federal University of Uberlândia, 87 cases of melanocytic lesions were diagnosed. These samples came from both male and female animals of different species and ages. All registered cases had a neoplasia diagnosis based on the $\mathrm{CH}$ analysis of samples embedded in paraffin and stained with HE. A total of 86 cases had a melanoma diagnosis - seventy-four with melanotic melanoma and twelve with amelanotic melanoma-and only one case had a melanocytoma diagnosis. Therefore, 75 cases were of pigmented lesions (Table $1-\mathrm{A}$ ). These lesion locations are described in Table $2-\mathrm{A}$, according to the diagnoses observed in the evaluated registries.

Table 1. Melanocytic lesions diagnosed by conventional histopathology (A) and by the melanin bleaching method (B), according to species, sex and age

\begin{tabular}{|c|c|c|c|c|c|}
\hline \multicolumn{6}{|c|}{ A- Conventional Histopathology $(n=87)$} \\
\hline Species $(n)$ & \multicolumn{2}{|c|}{$\operatorname{Sex}(\mathrm{n})$} & \multicolumn{3}{|c|}{$\operatorname{Age}^{*}(\mathrm{n})$} \\
\hline & Male & Female & Young & Adult & Old \\
\hline \multicolumn{6}{|c|}{ Melanotic melanoma $(\mathrm{n}=74)$} \\
\hline Canine (70) & 22 & 48 & 2 & 21 & 51 \\
\hline Equine (2) & 2 & - & - & 2 & - \\
\hline Bovine (1) & 1 & - & 1 & - & - \\
\hline Rodent (1) & 1 & - & - & - & 1 \\
\hline \multicolumn{6}{|c|}{ Amelanotic melanoma $(n=12)$} \\
\hline Canine (11) & 4 & 8 & - & 4 & 8 \\
\hline Feline (1) & - & 1 & - & 1 & - \\
\hline \multicolumn{6}{|c|}{ Melanocytoma $(\mathrm{n}=1)$} \\
\hline Canine (1) & - & 1 & 1 & - & - \\
\hline \multicolumn{6}{|c|}{ B - Melanin Bleaching $(n=75)$} \\
\hline Species (n) & \multicolumn{2}{|c|}{$\operatorname{Sex}(n)$} & \multicolumn{3}{|c|}{ Age (n) } \\
\hline & Male & Female & Young & Adult & Old \\
\hline \multicolumn{6}{|c|}{ Melanotic melanoma $(n=57)$} \\
\hline Canine (54) & 13 & 41 & 1 & 23 & 30 \\
\hline Equine (2) & 2 & - & - & 2 & - \\
\hline Rodent (1) & 1 & - & - & - & 1 \\
\hline \multicolumn{6}{|c|}{ Melanocytoma $(n=13)$} \\
\hline Canine (12) & 4 & 7 & 1 & 5 & 6 \\
\hline Bovine (1) & 1 & - & 1 & - & - \\
\hline \multicolumn{6}{|c|}{ Melanosis $(n=5)$} \\
\hline Canine (5) & 3 & 2 & - & 2 & 3 \\
\hline
\end{tabular}

*Young: $0-2$ years; adult: $3-8$ years; old: 9 or more 21 . 
Table 2. Localization of melanocytic lesions diagnosed by conventional histopathology (A) and by melanin bleaching method (B)

\begin{tabular}{|c|c|}
\hline \multicolumn{2}{|r|}{ A- Conventional histopathology $(\mathrm{n}=87)$} \\
\hline Species (n) & Localization (n) \\
\hline \multicolumn{2}{|r|}{ Melanotic melanoma $(n=74)$} \\
\hline Canine (70) & $\begin{array}{l}\text { Skin (51), oral (10), ocular (3), parenchymal (2), skin and parenchymal (2), oral } \\
\text { and skin (1), oral and parenchymal (1) }\end{array}$ \\
\hline Equine (2) & parenchymal (1), Skin (1) \\
\hline Bovine (1) & Skin (1) \\
\hline Rodent (1) & parenchymal (1) \\
\hline \multicolumn{2}{|r|}{ Amelanotic melanoma $(\mathrm{n}=12)$} \\
\hline Canine (11) & Oral (6), skin (4), skin and oral (1) \\
\hline Feline (1) & Oral (1) \\
\hline \multicolumn{2}{|r|}{ Melanocytoma $(\mathrm{n}=1)$} \\
\hline Canine (1) & Ocular (1) \\
\hline \multicolumn{2}{|r|}{ B - Melanin Bleaching $(n=75)$} \\
\hline \multicolumn{2}{|r|}{ Melanotic melanoma $(\mathrm{n}=57)$} \\
\hline Canine (54) & Skin (41), oral (10), parenchymal (3) \\
\hline Equine (2) & parenchymal (1) parenchymal (1) \\
\hline Rodent (1) & parenchymal (1) \\
\hline \multicolumn{2}{|r|}{ Melanocytoma $(\mathrm{n}=13)$} \\
\hline Canine (12) & Skin (9), ocular (3) \\
\hline Bovine (1) & Skin (1) \\
\hline \multicolumn{2}{|r|}{ Melanosis $(n=5)$} \\
\hline Canine (5) & Epidermal (2), ocular (1), parenchymal (1), epidermal and inflammatory (1) \\
\hline
\end{tabular}

The MB technique was applied to the 75 pigmented lesion samples. According to the previous tests, 15 minutes in the $0.3 \% \mathrm{KMnO} 4$ and $0.3 \% \mathrm{H} 2 \mathrm{SO} 4$ solution for all evaluated tissues was considered optimal treatment. The results did not present easy or difficult whitening depending on the lesion's location. The results of re-evaluating the samples using MB presented 57 cases $(76 \%)$ with a melanomas diagnosis (Figure 1 - A, B), 13 (17.33\%) with melanocytomas (Figure $1-\mathrm{C}, \mathrm{D})$, and five $(6.66 \%)$ with melanosis (Figure 1 - E, F). Therefore, these data presented a disagreement with 18 (24\%) diagnoses that were previously classified as melanotic melanoma.

In this work, three out of five melanosis cases were epidermal and diagnosed through the evaluation of the depigmented cuts. One case was parenchymal (lymph node), another ocular (choroid), and one dog presented both epidermal and inflammatory forms (nodule in the thoracic cavity collected at necropsy). The number of diagnosed melanocytic lesion cases identified using MB method, regarding the species, sex, and age of the affected animals, is shown in Table 1-B. The melanocytic lesion locations, according to diagnosis by this method, is shown in Table 2-B.

Diagnoses using the $\mathrm{CH}$ method and those after MB were compared by the Kappa test. The results of the MB method presented low agreement with $61.0 \%$ diagnoses and low Kappa coefficient of 0.2267 , therefore confirming the divergence between the methods (Table 3 ). 


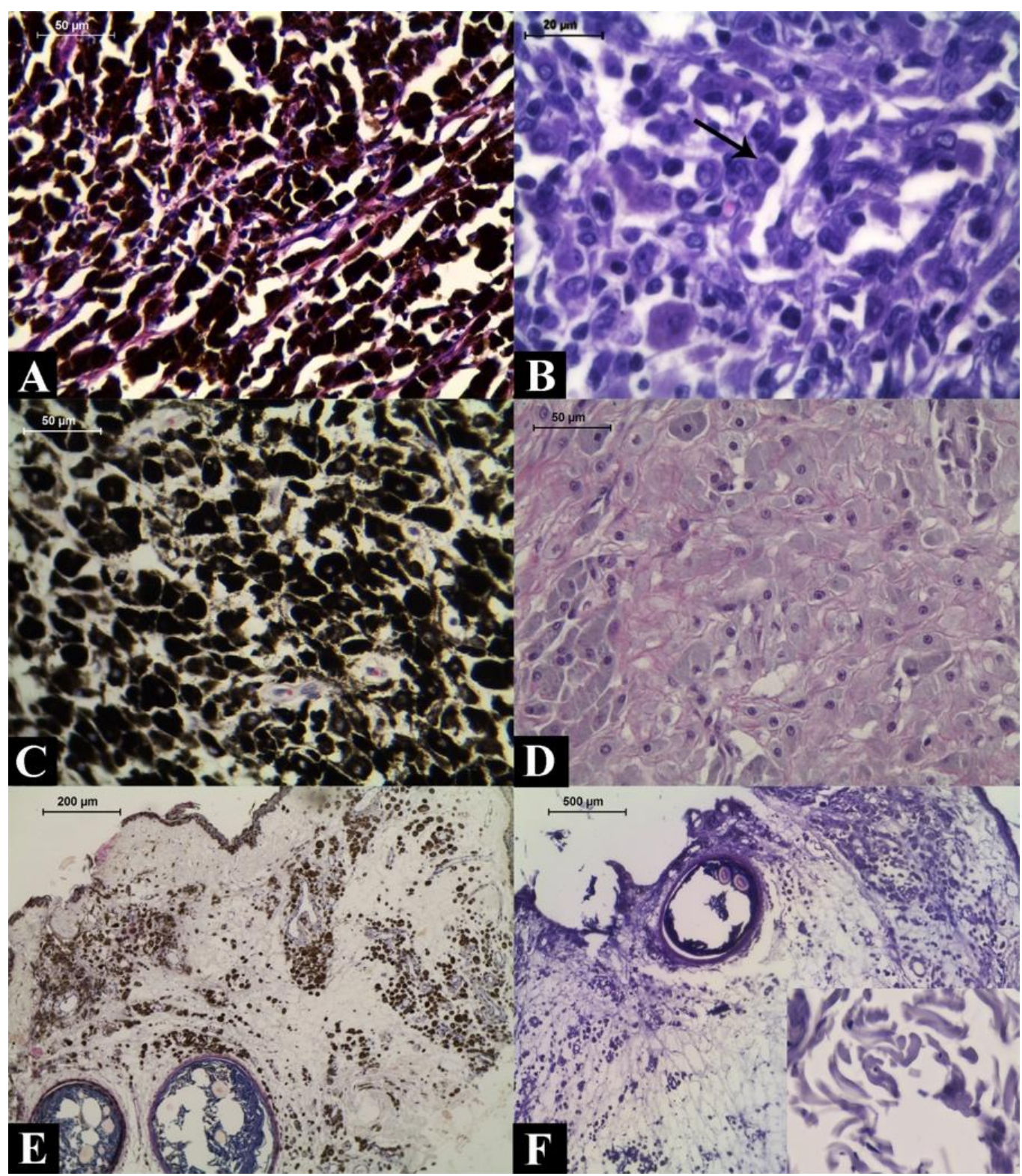

Figure 1. Photomicrographs of melanocytic lesions before and after melanin bleaching with KMnO4, $\mathrm{H} 2 \mathrm{SO} 4$ and $\mathrm{C} 2 \mathrm{H} 2 \mathrm{O} 4$. A and B: Oral melanoma, 13-year-old male non-breed dog. In A, cells group with a large amount of blackened pigment, without the possibility to evaluate their cellular characteristics; conventional histopathology, Hematoxylin and Eosin staining $(\mathrm{H} \& \mathrm{E})$, bar $=50 \mu \mathrm{m}$. In $\mathrm{B}$, melanin bleaching: cells with oval to elongated shape, hyperchromatic nuclei, high cellular atypia and mitotic figures (arrow), arranged between thin stroma of connective tissue; $\mathrm{KMnO} 4, \mathrm{H} 2 \mathrm{SO} 4$ and $\mathrm{C} 2 \mathrm{H} 2 \mathrm{O} 4, \mathrm{H} \& \mathrm{E}$ staining, bar $=20 \mu \mathrm{m}$. C and D: Cutaneous melanocytoma, 1-year-old male Senepol breed bovine. In C, cell group with large amount of blackened pigment, conventional histopathology, $\mathrm{H} \& \mathrm{E}$, bar $=50 \mu \mathrm{m}$. In $\mathrm{D}$, round cells with small, round and central nucleus, presenting discrete cellular pleomorphism and absence of mitotic figures; $\mathrm{KMnO} 4, \mathrm{H} 2 \mathrm{SO} 4$ and $\mathrm{C} 2 \mathrm{H} 2 \mathrm{O} 4, \mathrm{H} \& \mathrm{E}$ staining, bar $=50 \mu \mathrm{m}$. $\mathrm{E}$ and $\mathrm{F}$ : Epidermal melanosis, 7-year-old male Boxer breed dog. In E, cells with large amounts of blackened pigment dispersed between fibrous connective tissue and close to blood vessels; conventional histopathology, H\&E staining, bar $=200 \mu \mathrm{m}$. In F, round and regular contour cells - dispersed between fibrous tissue - with round, regular and evident contour nucleus, and absence of cellular pleomorphism and mitoses; 4x objective, $\mathrm{KMnO} 4, \mathrm{H} 2 \mathrm{SO} 4$ and $\mathrm{C} 2 \mathrm{H} 2 \mathrm{O} 4, \mathrm{H} \& \mathrm{E}$ staining, bar $=500 \mu \mathrm{m}$. 
Table 3. Kappa test analysis of the diagnoses established by conventional histopathology compared to the diagnoses established with melanin bleaching

\begin{tabular}{lr}
\hline Pigmented \\
melanocitic \\
lesions $(\mathrm{n}=75)$ & \multicolumn{2}{c}{\begin{tabular}{c} 
Method of evaluation \\
\hline Agreement $(\%)$
\end{tabular}} \\
\hline Kappa & 0,6133 \\
$\mathrm{P}$ & 0,2267 \\
$\mathrm{P} \leq 0,05^{*}$ & $<0,0001^{*}$ \\
\hline
\end{tabular}

The evaluation of the malignancy criteria, considering the diagnoses established with the $\mathrm{MB}$, presented frequent lesions in the affected tissue among the melanomas. The pagetoid spread was the most significant lesion in cutaneous melanomas; however, it was not observed in any melanocytoma case. The distribution of melanin was also another significant factor. The melanin had a nonuniform distribution in the tissues of most melanomas, but it presented uniformity in melanocytomas.

Using MB allowed the verification of the prevalence of two types of cell morphology in the melanomas, compared to those composed by cells with only one type of morphology. Moreover, in the most cases, the cells were arranged in clusters or nests, with ample cytoplasm, a small nucleus, and an evident nucleolus.

The other malignancy criteria (presence of inflammatory cells, cellular necrosis, and giant cell formation) were less frequent. In one melanocytoma case, the neoplasia resulted in tissue lesions; in this case, it was retinal rupture. These benign tumors were predominantly composed of one cell type, with isolated cells separated by fibrous stroma, broad cytoplasm, large nucleus, and discrete or imperceptible nucleolus. On the other hand, the melanosis presented melanocytes of rounded shape, broad cytoplasm, and generally, a large nucleus, and with wide distribution in the tissue (Table 4).

The MB was considered essential for diagnosis (score 3) in 37 (49.34\%) cases, significant (score 2) in $22(29.33 \%)$, and ineffective (score 1) in 16 $(21,33 \%)$.

Table 4. Frequency of histopathologic features in melanocytic lesions, evaluated with melanin bleaching method support

\begin{tabular}{|c|c|c|}
\hline \multicolumn{3}{|c|}{ Melanotic melanoma $(n=57)$} \\
\hline Histopathologic Features & \multicolumn{2}{|r|}{$\mathrm{n}(\%)$} \\
\hline Tissue alterations & Yes $=46(80,70 \%)$ & $\mathrm{No}=11(19,29 \%)$ \\
\hline Distribution of melanin & Uniform $=8(14,03 \%)$ & Irregular $=49(85,97 \%)$ \\
\hline Cell morphology & One type $=24(42,11 \%)$ & Two types $=33(57,89 \%)$ \\
\hline Cell distribution & Isolated $=17(29,82 \%)$ & Grouped $=40(70,18)$ \\
\hline Cytoplasm & Large $=33(57,89 \%)$ & Scarce $=24(42,11 \%)$ \\
\hline Nucleus & Small $=36(63,15 \%)$ & Large $=21(36,85 \%)$ \\
\hline Nucleoli & Prominent $=30(52,63 \%)$ & Discreet/imperceptible $=27(47,36 \%)$ \\
\hline Inflammatory cells & Yes $=19(33,34 \%)$ & No $=38(66,66 \%)$ \\
\hline Cell necrosis & Yes $=17(29,83 \%)$ & $\mathrm{No}=40(70,17 \%)$ \\
\hline Giant cells & Yes $=9(15,79 \%)$ & No $=48(84,21 \%)$ \\
\hline & Melanocytoma $(n=13)$ & \\
\hline Tissue alterations & Yes $=1(7,70 \%)$ & No $=12(92,30 \%)$ \\
\hline Distribution of melanina & Uniform $=12(92,30 \%)$ & Irregular $=1(7,70 \%)$ \\
\hline Cell morphology & One type $=8(61,53 \%)$ & Two types $=5(38,47 \%)$ \\
\hline Cell distribution & Isoladed $=11(84,61 \%)$ & Grouped $=2(15,39 \%)$ \\
\hline Cytoplasm & Large $=13(100 \%)$ & Scarce $=0$ \\
\hline Nucleus & Small $=6(46,15 \%)$ & Large $=7(54,75 \%)$ \\
\hline Nucleoli & Prominet $=5(38,46 \%)$ & Discreet/imperceptible $=8(61,64 \%)$ \\
\hline & Melanosis $(n=5)$ & \\
\hline Cell morphology & One type $=5(100 \%)$ & Two types $=0$ \\
\hline Cell distribution & Isolated $=5(100 \%)$ & Grouped $=0$ \\
\hline Cytoplasm & Large $=5(100 \%)$ & Scarce $=0$ \\
\hline Nucleus & Small $=2(40 \%)$ & Large $=3(60 \%)$ \\
\hline
\end{tabular}




\section{DISCUSSION}

The high occurrence of pigmented lesions found in this study shows the importance of adopting routine MB techniques in veterinary histopathology, like in human medicine (Momose et al., 2011; Liu et al., 2013; Chung et al., 2016). Furthermore, the disagreement on the diagnoses after re-evaluation using MB confirms the importance of using this method.

Melanoma is the most frequent melanocytic neoplasm in dogs (Teixeira et al., 2010; Gillard et al., 2013) which was verified in this study. This neoplasm has aggressive biological behavior, and a high incidence of metastases and relapses after treatment; therefore, its correct diagnosis is critical (Robinson and Ruxtable, 2003; Rhodes and Werner, 2011; Uzal et al., 2016). In addition, using MB in this study correctly diagnosed five cases of melanosis that were previously diagnosed as malignant melanoma.

Sub-terms - such as nevus, melanoderma, and melisma - are not commonly used in veterinary medicine, and this caused denomination to be used in melanosis and its classification according to its location. Furthermore, melanosis can occur in several organs (Goldschmidt and Goldschmidt, 2017), and for appropriate diagnosis, must also consider that melanosis is a common event in areas with chronic inflammation, (Robinson and Ruxtable, 2003), as observed in this study.

The epidemiological characteristics found in this work are congruent with other approaches in research, such as the greatest occurrence of melanomas in middle age or elderly non-breed dogs (Teixeira et al., 2010; Goldschmidt and Goldschmidt, 2017). However, although the sexual predisposition is not described, this work presented the greatest occurrence of both melanomas and melanocytomas in females. This result is different from those reported by other studies, in which the occurrence in males was higher (Teixeira et al., 2010; Gillard et al., 2013).

Regarding the melanocytic lesions' location, the literature describes a higher occurrence of melanomas in dogs in the nail, oral, and digit regions and the most frequent melanocytomas in the ocular and cutaneous regions (Camargo et al., 2008; Rhodes and Werner, 2011; Gillard et al., 2013). In this work, the re-evaluation after MB presented the melanocytoma was also most frequently found in cutaneous and ocular regions. However, the results showed that cutaneous melanomas appear the most in this type of neoplasia and the second most frequent was the oral melanoma.

The occurrence of malignancy criteria evaluated in this work agrees with the literature (PiñeiroMaceira, 2000; Veronese et al., 2007; Massi and Leboit, 2013). In addition, the presence of extensive pagetoid spread is a criterion that is more frequent evaluated cutaneous melanocytic lesions in humans (Urso et al., 2005; Smoller, 2006; Veronese et al., 2007) but is scarcely reported in veterinary medicine (Gross et al., 2005; Goldschmidt and Goldschmidt, 2017). However, it was found in high frequency in the cutaneous melanomas in this study. Choosing medical literature to establish the criteria evaluated in this study is due to the scarcity of systematic definitions for these parameters in the veterinary literature.

The veterinary literature (Gross et al., 2005) describes the majority of melanomas as composed of cells with fusiform and rounded appearance, presenting high atypia and a large amount of mitosis per field. Nonetheless, these authors reported pagetoid spread in melanocytomas and this was not found in this work.

The main MB techniques involve the use of a potassium permanganate solution followed by an oxalic acid solution (Shen and $\mathrm{Wu}, 2015$ ) which was performed in this study. Another method can also be used for melanocytes whitening by using $10 \%$ hydrogen peroxide. However, this technique has been applied only for immunohistochemical analysis due to the longer time necessary to prepare the slides (on average 24 hours); with the latter technique, no destruction of the epitopes occurs, which is different from the method with $\mathrm{KMnO} 4, \mathrm{H} 2 \mathrm{SO} 4$, and C2H2O4 (Silva et al., 2011).

Different times of cut permanence in the potassium permanganate and sulfuric acid solution have been described as: two minutes for skin samples, fifteen minutes for choroid and 
ciliary body, and thirty minutes for iris samples (Chesterman and Leach, 1958). However, the time used in this work-fifteen minutes-was effective for all samples, and a time below fifteen minutes was not sufficient for complete melanin removal from the samples with intense pigmentation.

Whitening methods are widely used in human medicine for histopathological diagnosis of melanocytic lesions; however, these methods have not been used in most recent animal studies, even in cases with very pigmented lesions (Semin et al., 2011; Teixeira et al., 2013; Bhadaniya et al., 2015; Pandey et al., 2016).

The MB was classified by the evaluators as essential for the diagnosis, with a score of 3 in most of the samples evaluated. Even when the diagnosis was in agreement after whitening with the conventional histopathological diagnosis, some cases were easier to evaluate in depigmented samples (score 2). The MB was considered ineffective for the diagnosis (score 1) in the minority of the cases. Fundamental criteria for determining malignancy or benignity, such as cellular morphological characteristics, nuclear evaluation, and counting of mitosis per field (Urso et al., 2005; Bergman et al., 2013; Goldschmidt and Goldschmidt, 2017) were possible in most samples only using MB.

\section{CONCLUSIONS}

This study demonstrated that the melanin bleaching technique with potassium permanganate, sulfuric acid, and oxalic acid solutions - together with the histopathological parameters analysis in bleaching slides - must be considered as an efficient complementary method for the melanocytic lesion diagnoses in veterinary medicine and its use is important even in cases when lesions have a moderate degree of pigmentation.

\section{REFERENCES}

AYRES, M.; AYRES JÚNIOR, M.; AYRES, D.L.; SANTOS, A.A.S. BioEstat: Aplicações estatísticas nas áreas das ciências bio-médicas. Versão 5.0, 2007. Available in: $<$ http://euler.mat.ufrgs.br/ giacomo/Manuaissoftw/BIOESTAT/Manual-BioEstat.pdf>. Accessed in: 21 Aug. 2017.
BERGMAN, P.J.; KENT, M.S.; FARESE, J.P. Melanoma. In: WITHROW, S.J.; VAIL, D.M. (Eds.). Withrow and MacEwen's small animal clinical oncology. St. Louis: Print Book, 2013. p.321-334.

BHADANIYA, A.R.; TRANGADIA, B.J.; PRASAD, M.C. et al. Pathology of melanocytic tumour in cattle. Indian J. Vet. Pathol., v.39, p.249-250, 2015.

CAMARGO, L.P.; CONCEIÇÃO, L.G.; COSTA, P.R.S. Neoplasias melanocíticas cutâneas em cães: estudo retrospectivo de 68 casos (1996-2004). Braz. J. Vet. Res. Anim. Sci., v.45, p.138-152, 2008.

CHESTERMAN, W.; LEACH, E.H. A bleaching method for melanin and two staining methods. Q. J. Microsc. Sci., v.1, p.65-66, 1958.

CHUNG, J.; CHOI, J.; SEARS, J.D. et al. A melanin-bleaching methodology for molecular and histopathological analysis of formalin-fixed paraffin-embedded tissue. Lab. Invest., v.00, p.112, 2016.

GILlARD, M.; CADIEU, E.; BRITO, C. et al. Naturally occurring melanomas in dogs as models for non-UV pathways of human melanomas. Pigment Cell Melanoma Res., v.27, p.90-102, 2013.

GOLDSCHMIDT, M.H.; GOLDSCHMIDT, K.H. Epithelial and melanocytic tumors of the skin. In: MEUTEN, D.J. (Ed.). Tumors in domestic animals. Iowa: John Wiley \& Sons Inc., 2017. p.88-136.

GROSS, T.L.; IHRKE, P.J.; WALDER, E.J.; AFFOLTER, V.K. Melanocytic tumors. In: . (Eds.). Skin diseases of the dog and cat clinical and histopathologic diagnosis. Iowa: Wiley-Blackwell, 2005. p.813-836.

LIU, C.H.; LIN, C.H.; TSAI, M.J. et al. Melanin bleaching with dilute hydrogen peroxide: a simple and rapid method. Appl. Immunohistochem. Mol. Morphol., v.21, p.275279, 2013.

MASSI, G.; LEBOIT, P.E. (Eds.). Histological diagnosis of nevi and melanoma. New York: Springer, 2013. 572p. 
MILLER, M.A.; ZACHARY, J.F. Mechanisms and morphology of cellular injury, adaptation and death. In: ZACHARY, J.F (Ed.). Pathologic basis of veterinary disease: expert consult. St. Louis: Print Book, 2017. p.36-37.

MOMOSE, M.; OTA, H.; HAYAMA, M. Reevaluation of melanin bleaching using warm diluted hydrogen peroxide for histopathological analysis. Pathol. Int., v.61, p.345-350, 2011.

PANDEY, M.K.; TRIPATHI, R.M.; TRIPATHI, S.M. et al. Benign melanocytoma in a nondescript cow: a case report. Indian J. Anim. Res., v.50, p.632-633, 2016.

PIÑEIRO-MACEIRA, J. Critérios mínimos para o diagnóstico do melanoma. Bol. Inf. Grupo Bras. Melanoma, v.3, p.1-6, 2000.

RHODES, K.H.; WERNER, A.H. (Eds.). Blackwell's five-minute veterinary consult clinical companion: small animal dermatology. Ames: Wiley-Blackwell, 2011. 768p.

ROBINSON, W.E.; RUXTABLE, C.R.R. (Eds.). Clinicopathologic principles for veterinary medicine. Cambridge: Cambridge University Press, 2003. 452p.

SEMIN, M.O.; SERRA, F.; MAHE, V. et al. Choroidal melanocytoma in a cat. Vet. Ophthalmol., v.14, p.205-208, 2011.

SHEN, H.; WU, W. Study of Melanin Bleaching After Immunohistochemistry of Melanincontaining Tissues. Appl. Immunohistochem. Mol. Morphol., v.23, p.303-307, 2015.
SILVA, A.P.; SILVA, R.G.; COGLIATI, B. et al. Bleaching of melanin in the epidermis of South American fur seal and its application on enzyme immunohistochemistry. Pesqui. Vet. Bras., v.31, p.267-270, 2011.

SMOLLER, B.R. Histologic criteria for diagnosing primary cutaneous malignant melanoma. Mod. Pathol., v.19, p.34-40, 2006.

TEIXEIRA, C.; PIRES, I.; FERREIRA, S.; VIEIRA-PINTO, M. Lesões melanocíticas em suínos abatidos para consumo. Arq. Bras. Med. Vet. Zootec., v.65, p.783-791, 2013.

TEIXEIRA, T.F.; SILVA, T.C.; COGLIATI, B. et al. Retrospective study of melanocytic neoplasms in dogs and cats. Braz. J. Vet. Pathol., v.3, p.100-104, 2010.

URSO, C.; RONGIOLETTI, F.; INNOCENZI, D. et al. Histological features used in the diagnosis of melanoma are frequently found in benign melanocytic naevi. J. Clin. Pathol., v.58, p.409-412, 2005.

UZAL, F.A.; PLATTNER, B.L.; HOSTETTER, J.M. Alimentary sistem. In: JUBB, K. V.F.; KENNEDY, P.C.; PALMER, N. (Eds.). Pathology of domestic animals. St. Louis: Saunders, 2016. p.26-27.

VERONESE, L.A.; CORRENTE, J.E.; MARQUES, M.E.A. Critérios histopatológicos para diagnóstico de melanoma maligno cutâneo: análise comparativa de sua frequência em lesões benignas e melanomas de pequena espessura $(<$ 2mm). J. Bras. Patol. Med. Lab., v.43, p.363368, 2007. 